\title{
Endocrine and metabolic changes in transition dairy cows are affected by prepartum infusions of a serotonin precursor
}

\author{
Lorenzo E. Hernández-Castellano, ${ }^{*}$ Laura L. Hernandez, $†$ Helga Sauerwein, $\ddagger$ and Rupert M. Bruckmaier ${ }^{* 1}$ \\ *Veterinary Physiology, Vetsuisse Faculty, University of Bern, 3012 Bern, Switzerland \\ †Department of Dairy Science, University of Wisconsin, Madison 53706 \\ łInstitute of Animal Science, Physiology and Hygiene Unit, University of Bonn, 53115 Bonn, Germany
}

\begin{abstract}
Serotonin (5-HT) has been shown to be involved in calcium homeostasis, modulating calcium concentration in blood. In addition, 5-HT participates in a variety of metabolic pathways, mainly through the modulation of glucose and lipid metabolism. The hypothesis of the present study was that the prepartum administration of 5-hydroxy-L-tryptophan (5-HTP), a 5-HT precursor, would affect endocrine systems related to calcium homeostasis, and interact with other endocrine and metabolic pathways during the transition period. In this study, 20 Holstein dairy cows were randomly assigned to 2 experimental groups. Both groups received a daily i.v. infusion of $1 \mathrm{~L}$ of either $0.9 \% \mathrm{NaCl}$ (control group; $\mathrm{n}=10$ ) or $0.9 \% \mathrm{NaCl}$ containing $1 \mathrm{mg}$ of 5 -HTP $/ \mathrm{kg}$ of BW (5-HTP group, $\mathrm{n}=10$ ). Infusions started d 10 before estimated parturition date and ended the day of parturition, resulting in a minimum of $4 \mathrm{~d}$ of infusion (8.4 $\pm 0.7 \mathrm{~d}$ of infusion). Until parturition, blood samples were collected before the daily infusions, and postpartum daily until d 7 , and on $\mathrm{d} 30$. Plasma concentrations of parathyroid hormone (PTH) were transiently increased at parturition and on $\mathrm{d} 1$ in control cows. In the 5-HTP group PTH remained unchanged. The concentration of pyridinoline (PYD), an established marker for calcium release from the bone to the bloodstream, increased on d 1 postpartum only in the 5-HTP group. In control cows, PYD concentrations did not change on d 1 postpartum. Melatonin concentrations were slightly but significantly increased in the 5-HTP group compared with the control group. Insulin concentrations decreased in both groups postpartum. Before parturition, leptin concentrations decreased in both groups and remained at this level until d 30 postpartum. Plasma IgG concentrations decreased in both groups on $\mathrm{d}-1$ postpartum. Haptoglobin increased in
\end{abstract}

Received December 12, 2016.

Accepted February 28, 2017.

${ }^{1}$ Corresponding author: rupert.bruckmaier@vetsuisse.unibe.ch both groups on $\mathrm{d}-1$ and remained at this level until d 7 postpartum. No differences between groups were observed for insulin, glucagon, IgG, leptin, adiponectin, and haptoglobin concentrations. The results obtained in the present study evidenced that 5-HT is regulating calcium homeostasis independent of PTH. The lack of treatment effects on IgG and on other hormones and metabolites indicates that 5-HTP did not affect these other metabolic pathways and the IgG concentration during the transition period.

Key words: serotonin, hypocalcemia, metabolism, 5-hydroxy-L-tryptophan, parathyroid hormone

\section{INTRODUCTION}

The transition period is considered most challenging and critical in relation to the dairy cow's health status during the lactation cycle (Kessel et al., 2008). Major physiological, nutritional, metabolic, and immunological changes take place due to the onset of milk secretion, concomitantly with parturition (Drackley, 1999; Gross et al., 2011). The metabolic load makes cows susceptible to production diseases such as metritis, ketosis, mastitis, or hypocalcemia during the transition period (Fleischer et al., 2001; Van Knegsel et al., 2014). Serotonin (5-hydroxytryptamine, 5-HT), a monoamine synthesized from the AA L-tryptophan, is synthesized by the central nervous system, but also by various peripheral tissues including the mammary gland (Lauder, 2004). Serotonin has been demonstrated to be an autocrine regulator of mammary gland metabolism, including calcium homeostasis (Hernandez et al., 2012; Laporta et al., 2015) and milk synthesis (Matsuda et al., 2004). Recently, Weaver et al. (2016) and Hernández-Castellano et al. (2017) demonstrated that the infusion of the 5-HT precursor 5-hydroxytryptophan (5-HTP) during the last days before parturition improved blood calcium concentrations around parturition. Additionally, 5-HT has been shown to influence several metabolites related to glucose and lipid metabolism such as glucose, insulin, triglyceride, cholesterol, and fatty acid concentrations in mice (Sugimoto et al., 
1990; Watanabe et al., 2010) and sheep (Watanabe et al., 2014). Moreover, 5-HT promotes the proliferation and activation of B cells in mice (Iken et al., 1995), and therefore the $\operatorname{IgG}$ concentration could also be affected by the increased 5-HT concentration in blood. Similar effects have so far not been demonstrated in dairy cows. Based on the known functions of 5-HT, we have tested the hypothesis that the administration of 5-HTP prepartum will affect different endocrine factors related to calcium homeostasis and will interact also with other immune, endocrine, and metabolic pathways during the transition period.

\section{MATERIALS AND METHODS}

In this study, animal health status was monitored and animals did not show any symptoms of illness. This trial was approved by the Cantonal Committee for Animal Experiments (Canton of Fribourg, Switzerland), and all experimental procedures followed the Swiss law of animal protection.

\section{Animals and Treatments}

Twenty multiparous Holstein dairy cows from the experimental herd of the Agroscope Institute for Livestock Science research farm (Posieux, Switzerland) were used in this study. The day before the initiation of the infusions (B), cows were fitted with indwelling i.v. catheters (Abbocath-T, Hospira Deutschland $\mathrm{GmbH}$, Munich, Germany) with a length of $14 \mathrm{~cm}$ and a diameter of $14 \mathrm{G}$ in a jugular vein. Both groups received a daily i.v. infusion of $1 \mathrm{~L}$ over $1 \mathrm{~h}(0700-0800$ h) of either $0.9 \% \mathrm{NaCl}$ (control group) or $0.9 \% \mathrm{NaCl}$ containing $1 \mathrm{mg}$ of $5-\mathrm{HTP} / \mathrm{kg}$ of BW (5-HTP group) from $\mathrm{d}-10$ before the predicted parturition date until parturition. As described by Hernández-Castellano et al. (2017), this 5-HTP dosage caused an increase in serum 5-HT concentration from $5.49 \mu \mathrm{mol} / \mathrm{L}$ up $(5-\mathrm{HT}$ concentration B) to $12.94 \mu \mathrm{mol} / \mathrm{L}$ on $\mathrm{d}-4$ prepartum, and maintaining 5-HT concentrations at elevated level until d 5 postpartum $(9.75 \mu \mathrm{mol} / \mathrm{L})$. Blood samples were collected every morning before the infusions, and postpartum daily until $\mathrm{d} 7$. An additional sample was collected on d 30 postpartum. Cows were fed according to the guidelines published by Agroscope (2015). Briefly, cows received hay ad libitum (DM content, 890 $\mathrm{g} / \mathrm{kg}$ of fresh matter, on a DM basis, consisting of $125 \mathrm{~g}$ of CP $/ \mathrm{kg}, 235 \mathrm{~g}$ of crude fiber $/ \mathrm{kg}, 14.6 \mathrm{~g} / \mathrm{kg}$ of calcium, and 5.7 MJ of $\mathrm{NE}_{\mathrm{L}} / \mathrm{kg}$ ) and had free access to water. In addition, cows received a concentrate supplementation (6 MJ of $\mathrm{NE}_{\mathrm{L}} / \mathrm{kg}$ of $\mathrm{DM}$ and $5 \mathrm{~g}$ of calcium $/ \mathrm{kg}$ ) preand postpartum (0.5 and $2.5 \mathrm{~kg}$ per day and cow, respectively). In addition, cows were supplemented with a vitamin/mineral premix providing $2.5 \mathrm{~g}$ of calcium/d prepartum and $31.8 \mathrm{~g}$ of calcium/d postpartum.

\section{Sample Collection}

Blood samples were taken from the jugular catheter $(0700 \mathrm{~h})$ and placed into tubes for serum collection as well as tubes for plasma collection, containing $3 \mathrm{~K}$ EDTA. During the prepartum period, blood samples were always collected before the daily infusion of either control or treatment solution. Blood was stored either on wet ice (plasma tubes) or at room temperature (serum tubes) until centrifugation at 2,500 $\times g$ for $20 \mathrm{~min}$ at $4^{\circ} \mathrm{C}$ to obtain either plasma or serum, which was stored at $-80^{\circ} \mathrm{C}$ until analyses.

\section{Variables Measured in Plasma and Serum}

Plasma insulin concentration was measured by RIA as described by Vicari et al. (2008). Plasma glucagon concentration was measured by using a commercial RIA kit (catalog no. GL-32K, Millipore AG, Zug, Switzerland). Commercial ELISA kits were used to determine melatonin (catalog no. RE54021, IBL-International, Hamburg, Germany) and parathyroid hormone (PTH) in plasma (catalog no. 60-3500, Immutopics, Athens, $\mathrm{OH}$ ). Serum pyridinoline (PYD) was measured by ELISA using the MicroVue PYD EIA kit (catalog no. 8019, Quidel MicroVue, San Diego, CA). Serum adiponectin concentration was measured by ELISA as described by Kesser et al. (2015). Serum leptin concentration was measured by ELISA as described by Sauerwein et al. (2004), and haptoglobin (Hp) concentration was measured in serum by enzyme immunoassay as described by Hiss et al. (2009). The serum used had been calibrated against a standard obtained from a European Union Concerted Action on the standardization of animal acute phase proteins (QLK5-CT-1999-0153; Skinner, 2001). The parathyroid hormone-related protein (PTHrP) concentrations were measured using the Active PTHrP IRMA kit (\#DSL8100, Beckman Coulter GmbH, Sinsheim, Germany). Total IgG concentration in plasma was measured using a commercial ELISA kit specific to bovine IgG (Bethyl Laboratories, Montgomery, TX) with some modifications as described by Lehmann et al. (2015). Total serum calcium concentration was determined using a commercial kit from Diatools (DIA00461, Diatools AG, Villmergen, Switzerland).

\section{Statistical Analysis}

Results are presented as means \pm standard error of the mean. Statistical analyses were performed by using 
a linear mixed model with repeated measures (MIXED procedure) using SAS software (version 9.4, SAS Institute Inc., Cary, NC). The final model included the animal as a repeated effect and the treatment (control vs. 5-HTP), experimental period (B and from $\mathrm{d}-4$ to 30 postpartum), and interaction between both as dependent variables. Significant differences between groups were localized by Tukey-Kramer test. Values were considered significant when $P<0.05$.

\section{RESULTS}

As described recently, infusions started $10 \mathrm{~d}$ before the expected parturition (Hernández-Castellano et al., 2017). Because the day of parturition in the experimental animals ranged between d 279 to 286 of pregnancy, infusions were performed for a range of 4 to $10 \mathrm{~d}$ before parturition. The distribution of days of gestation at parturition did not differ between treatments (280.5 \pm 0.9 vs. $280.6 \pm 1.0 \mathrm{~d}$ of pregnancy in the control and 5-HTP groups, respectively). None of the studied variables were affected by the number of 5 -HTP infusions per cow prepartum ( 7 to 10 infusions vs. 4 to 6 infusions). Data obtained at B and from $\mathrm{d}-4$ to 30 postpartum were used for statistical evaluations. No differences in the feed intake of the concentrate were observed between groups during the experimental period. In this study, hay was offered ad libitum and therefore feed intake of the hay was not recorded.

Parathyroid hormone-related protein concentrations were below detection limit $(8.5 \mathrm{pg} / \mathrm{mL})$ of the kit in several cows and therefore no statistical comparisons regarding this hormone could be performed.

Parathyroid hormone concentrations (Figure 1A) were similar in both groups at $\mathrm{B}(P>0.05)$. In the 5-HTP group, PTH concentrations remained unchanged during the entire experimental period. In contrast, PTH was increased in the control group at parturition and on d 1 compared with $\mathrm{B}(P<0.05)$, decreasing again on $\mathrm{d} 2$ and remaining at this level until d 30. Differences in PTH concentration between 5-HTP and control groups were observed at parturition and on $\mathrm{d} 1$, with the highest concentrations observed in control cows $(P<0.05)$. Prior to the start of the infusions, PYD concentrations were similar in control and 5 -HTP groups $(3.10 \pm 0.24$ vs. $2.90 \pm 0.14 \mathrm{nmol} / \mathrm{L}$, respectively, $P>0.05)$. Concentrations of PYD, in the 5 -HTP treated cows only, were increased on d $1(P<$ $0.05)$ compared with values on $\mathrm{B}(\Delta 0.20 \pm 0.18$ and $\Delta 0.87 \pm 0.12 \mathrm{nmol} / \mathrm{L}$ in the control and the 5 -HTP groups, respectively).

Serum calcium levels were similar in both groups at the beginning of the experiment $(P>0.05)$. Around parturition, serum calcium decreased and reached a nadir on d 1 postpartum. However, calcium levels decreased by $28 \pm 1 \%$ in the control cows, but significantly less by $14 \pm 1 \%$ in the cows that received the prepartum infusion of 5-HTP $(P<0.05)$. In both groups, calcium levels were restored to prepartum levels from d 3 to the end of the experimental period. The detailed patterns of serum calcium concentrations in both groups have been published recently (HernándezCastellano et al., 2017).

Prior to the start of the infusions, plasma melatonin concentrations (Figure 1B) were similar in both groups $(P>0.05)$. Melatonin concentrations remained unchanged throughout the experimental period in the control group but were elevated in the 5-HTP group from $\mathrm{d}-4$ to 7 postpartum compared with $\mathrm{B}(P<$ $0.05)$. From d -3 to 7 and on d 30 postpartum, mela-
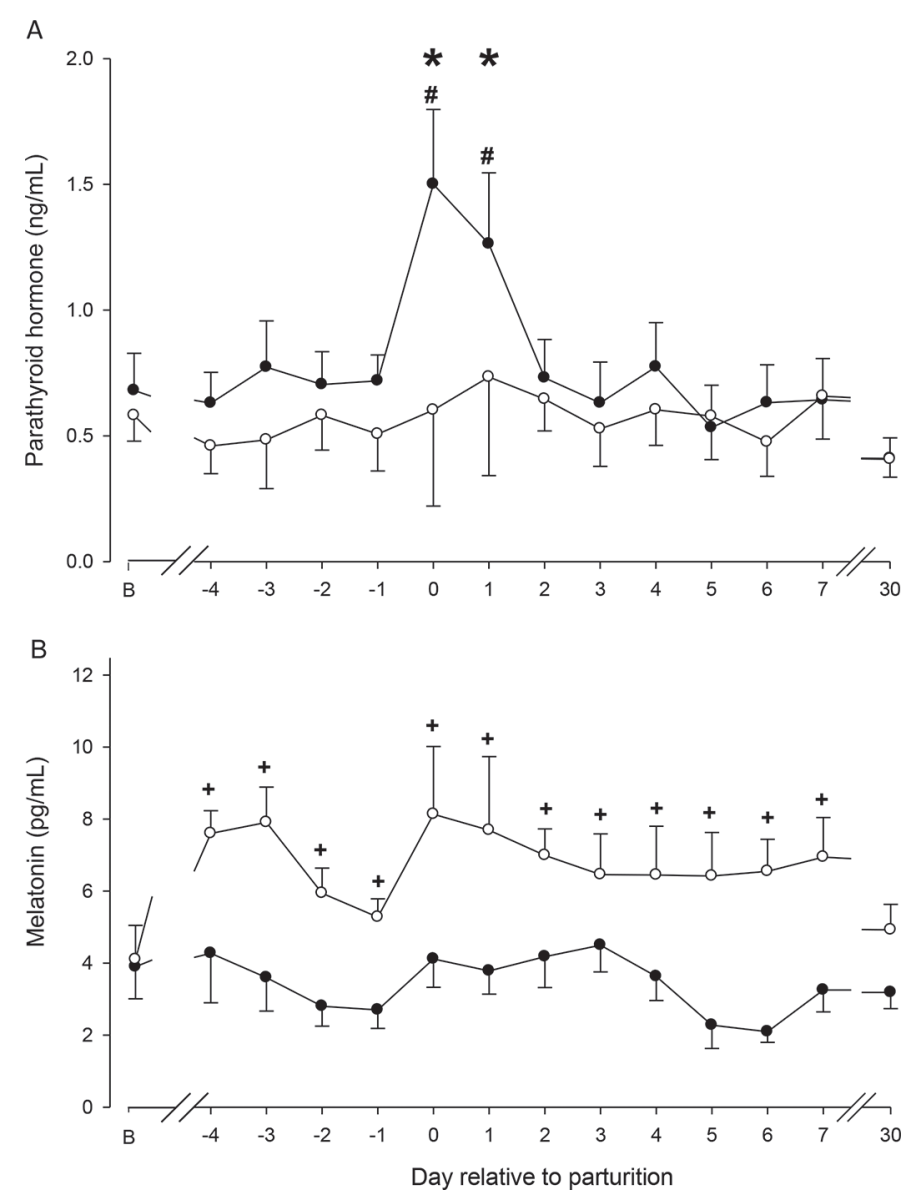

Figure 1. Parathyroid hormone (A) and melatonin (B) concentrations of cows administered prepartum saline (control; - or $1 \mathrm{mg} / \mathrm{kg}$ of BW 5-hydroxy-L-tryptophan (5-HTP; O) during the experimental period. \#Indicates a difference compared with $\mathrm{B}$ in the control group $(P$ $<0.05)$. + Indicates a difference to B in the 5 -HTP group $(P<0.05)$. *Indicates a difference between control and 5-HTP groups within each time point $(P<0.05)$. B = before the start of the infusions. Error bars indicate the standard error of the mean. 
tonin concentrations were increased in the 5-HTP cows compared with the control cows $(P<0.05)$.

Plasma insulin concentrations were similar between groups at $\mathrm{B}(P>0.05)$. Insulin reached the highest concentration on $\mathrm{d}-3$ (Figure $2 \mathrm{~A}$ ), decreased on $\mathrm{d}$ 3 and d 4 postpartum in 5-HTP and control groups, respectively, and remained at this lower level until d 7 postpartum $(P<0.05)$. On d 30, insulin concentrations returned to similar values as B. No differences were observed between treatment groups during the entire experimental period. Plasma glucagon concentrations (Figure 2B) remained unchanged in both groups from $\mathrm{B}$ until $30 \mathrm{~d}$ postpartum $(P>0.05)$. No differences in glucagon concentrations were observed between groups throughout the entire experimental period $(P>0.05)$.

Plasma IgG concentrations (Figure 2C) decreased in both groups on $\mathrm{d}-1$ prepartum compared with $\mathrm{B}(P<$ $0.05)$. The concentration of IgG did not differ between groups throughout the entire experimental period $(P$ $>0.05)$.

No differences in serum leptin concentration (Figure 3A) between 5-HTP and control groups were observed B $(P<0.05)$. Leptin concentrations decreased prepartum and were at the lowest at parturition in both groups $(P<0.05)$. Leptin was not affected by the infusion of 5-HTP $(P>0.05)$. Prior to the start of the infusions, no differences in adiponectin concentrations (Figure 3B) were detected between groups $(P>$ $0.05)$. Adiponectin did not significantly change during the experimental period and was not different between treatment control and 5-HTP-treated cows $(P>0.05)$. No differences in Hp concentrations (Figure 3C) were detected between control and 5-HTP treated cows at $\mathrm{B}(P>0.05)$. Haptoglobin concentrations gradually increased in both treatment groups from B to $\mathrm{d} 7$ with the highest concentrations observed on $\mathrm{d} 4$ and 5 in the control and 5-HTP groups, respectively $(P<0.05)$.

\section{DISCUSSION}

Differences in PTH concentrations between 5-HTP and control groups indicate the effect of increased 5-HT on calcium metabolism and its endocrine regulation. In previous studies from Weaver et al. (2016) and Hernández-Castellano et al. (2017), the regulation of calcium homeostasis by 5 -HT was demonstrated by the observation that calcium concentrations in control cows were decreased in blood to a greater extent than in cows receiving 5-HTP infusions on 1 and 2 postpartum. As the administration of 5-HTP did not result in changes in circulating PTH concentrations, it is obvious that 5 -HT regulates calcium homeostasis through a different pathway to the one used by the PTH. No literature has been found about the effect of 5-HT on the PTH recep-
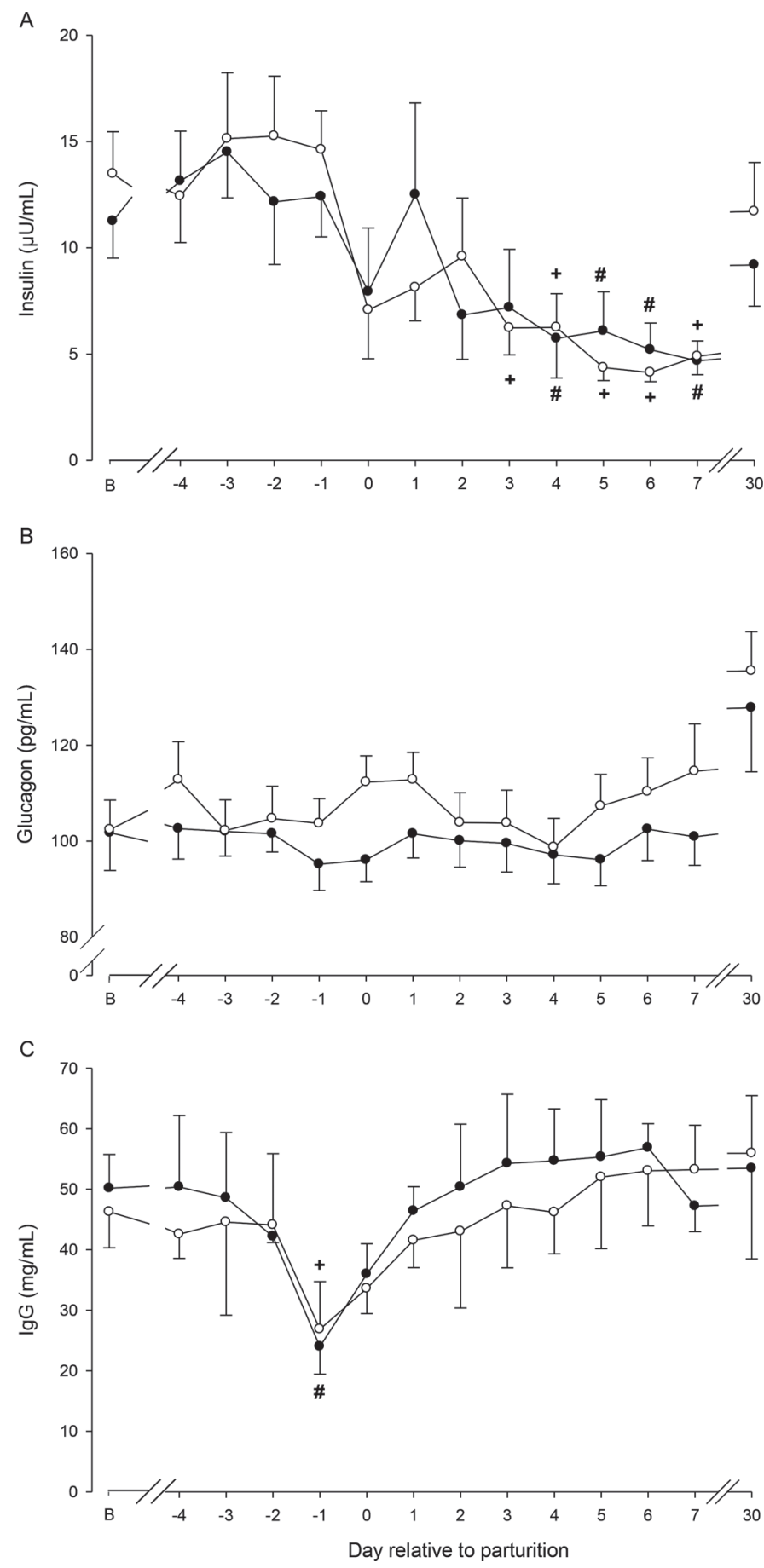

Figure 2. Insulin (A), glucagon (B), and IgG (C) concentrations of cows administered prepartum saline (control; $)$ or $1 \mathrm{mg} / \mathrm{kg}$ of BW 5-hydroxy-L-tryptophan (5-HTP; $\bigcirc)$ during the experimental period. \#Indicates a difference compared with $\mathrm{B}$ in the control group $(P<$ $0.05)$. + Indicates a difference to B in the 5 -HTP group $(P<0.05)$. B $=$ before the start of the infusions. Error bars indicate the standard error of the mean. 

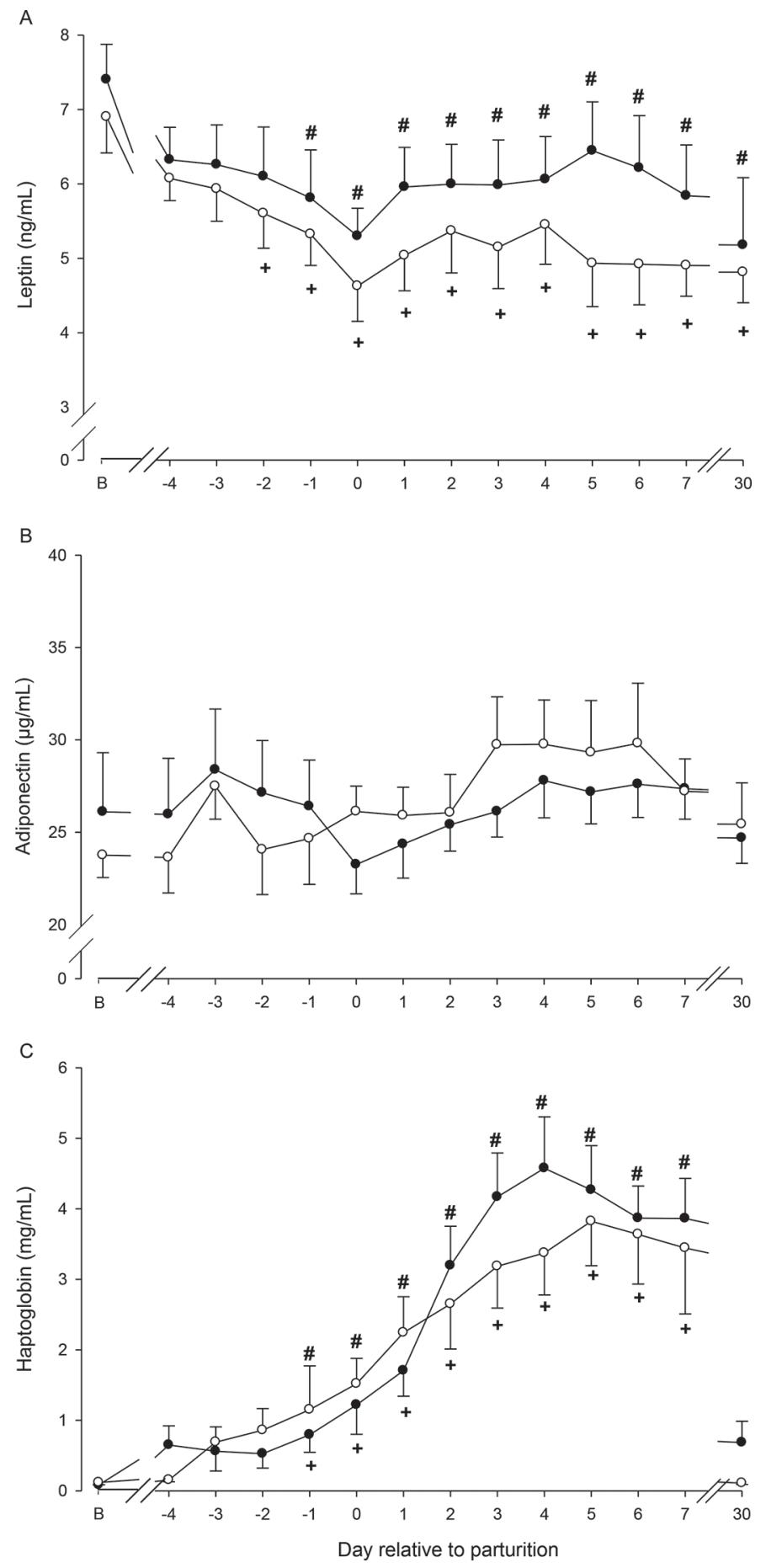

Figure 3. Leptin (A), adiponectin (B), and haptoglobin (C) concentrations of cows administered prepartum saline (control; - ) or 1 $\mathrm{mg} / \mathrm{kg}$ of BW 5-hydroxy-L-tryptophan (5-HTP; O) during the experimental period. \#Indicates a difference compared with $\mathrm{B}$ in the control group $(P<0.05)$. + Indicates a difference to $\mathrm{B}$ in the 5 -HTP group $(P$ $<0.05)$. B = before the start of the infusions. Error bars indicate the standard error of the mean. tors in the bone. Hernandez et al. (2012) and Laporta et al. (2014b) showed the stimulatory effect of increased 5 -HT concentrations on the secretion of mammaryderived PTHrP in mice. As described in humans and mice, PTHrP acts on bone tissue to release calcium into the bloodstream (Wysolmerski, 2010). In the present study, the concentration of PYD was increased by the infusion of 5-HTP. Pyridinoline is one of the components that covalently link collagen molecules in bone matrix (Romero Barco et al., 2012). During bone resorption, collagen is degraded and PYD is released into the bloodstream (Urena et al., 1995). Pyridinoline has been used as a marker for calcium release from the bone to the bloodstream in earlier studies (Urena et al., 1995; Eastell et al., 1997). Around parturition, bone resorption is of greater magnitude than is bone formation (Halloran and DeLuca, 1980). Therefore, PYD was used in the present study as a bone resorption marker before the start of the infusions and on $d 1$ postpartum when calcium mobilization is supposed to be more active. These results show that cows infused with 5-HTP prepartum had increased calcium mobilization from bone on d 1 postpartum than control cows. Therefore, these results confirm the action of 5 - $\mathrm{HT}$ on the regulation of calcium homeostasis, by increasing calcium mobilization from bone. The lack of effect on PTH concentrations by 5 -HTP treatment support the hypothesis of earlier research about the mechanism of 5-HT through PTHrP (Matsuda et al., 2004; Hernandez et al., 2012; Laporta et al., 2014a).

Apart from the role in the CNS and in many peripheral tissues, 5 - $\mathrm{HT}$ is also a melatonin precursor in the pineal gland. As 5-HTP is able to freely cross the blood-brain barrier (Rahman et al., 1982; Marshall et al., 2014), cows receiving the 5-HTP infusion in the present study exhibited increased melatonin concentrations in the blood. Although extra-pineal sites of melatonin production are present, such as the retina and the gut, the physiological significance of these sources to the total melatonin produced in the body is uncertain (Peuhkuri et al., 2012). In our study, blood samples were collected at $0700 \mathrm{~h}$, which is the time when melatonin concentrations are low compared with the elevated concentrations during the night (25.4 pg/ $\mathrm{mL}$ at $0100 \mathrm{~h}$; Castro et al., 2011). In addition, melatonin concentrations in the control group were similar to those observed by Castro et al. (2011) at $0700 \mathrm{~h}$ in dairy cows $(\simeq 5 \mathrm{pg} / \mathrm{mL})$. It has been described how increased melatonin concentrations decreased prolactin concentrations in dairy cows during dry-off (Garcia-Ispierto et al., 2013) and in mid-lactation (Auldist et al., 2007), decreasing milk yield in all cases. In cows receiving the 5-HTP infusions, melatonin concentrations were significantly elevated compared with controls; however, 
these concentrations are much lower than those seen in other studies where melatonin was administered either by a subcutaneous implant (Auldist et al., 2007; Garcia-Ispierto et al., 2013) or through an oral gelatin capsule containing the hormone (Lacasse et al., 2014). Consequently, we do not expect a significant physiological effect caused by the relatively moderate elevation of melatonin in the 5-HTP group.

In our study, the prepartum infusion of 5-HTP did not affect insulin and glucagon patterns during the experimental period. Those results are in agreement with our previously presented results where glucose concentrations were not affected by prepartum 5-HTP infusions (Hernández-Castellano et al., 2017). The observed decreased insulin concentration in both groups postpartum is related to the onset of lactation when blood glucose concentrations are low as the mammary gland uses glucose for energy and the synthesis of lactose (Weber et al., 2016). This insulin pattern postpartum in dairy cows has been already described by several authors (Lucy, 2004; Gross et al., 2011; Weber et al., 2016). These results reflect that the infusion of 5 -HTP is able to regulate calcium homeostasis without affecting regulatory pathways of carbohydrate and energy metabolism during early lactation.

Besides its role in calcium homeostasis, 5-HT has a direct effect on several processes in the immune system, such as the proliferation and activation of $\mathrm{T}$ and $\mathrm{B}$ cells in mice (Iken et al., 1995; Mossner and Lesch, 1998). In our study, the infusion of 5-HTP did not affect plasma IgG concentrations. The lack of effect shown in this study could be due to the short time that cows were treated with 5-HTP. It may be too short to induce a considerable proliferation or activation of the $\mathrm{B}$ cells and therefore an increase of the IgG concentration in blood.

Insulin has been described to stimulate secretion of leptin (Block et al., 2001; Sadri et al., 2011) and adiponectin (Blumer et al., 2008) by the adipocytes. In the present study, the 5-HTP dosage did not affect either leptin or adiponectin concentrations. In addition, leptin concentrations decreased in both groups at parturition, which was likely caused by the characteristic negative energy balance that occurs at the onset of lactation (Vernon et al., 2002; Gross et al., 2011). Those results are in agreement with Sadri et al. (2011) who observed decreased leptin concentrations $1 \mathrm{~d}$ postpartum compared with values obtained 8 wk prepartum. Singh et al. (2014) described that adiponectin concentrations also decreased as a consequence of the onset of lactation; however, in our study adiponectin remained unchanged throughout the entire study period. Possibly, adiponectin concentrations start to decrease several weeks prepartum, as demonstrated by Singh et al. (2014), and therefore it was already low at the beginning of our study.

Changes in energy status and lipid mobilization during the transition period can lead to excessive free fatty acid infiltration of the liver (Huzzey et al., 2011; Weber et al., 2013), representing a harmful stimulus to liver parenchymal cells and in consequence increasing the production of hepatic Hp (Katoh, 2002). In the present study, the increased $\mathrm{Hp}$ concentrations from d -1 to 7 may be caused by the parturition-related tissue lesions and inflammatory reactions of the genital tract (Saremi et al., 2012) as well as by the metabolic stress caused by negative energy balance around parturition (Huzzey et al., 2011). In the present study, no differences in the Hp concentrations were observed between groups during the studied period. As described by Hernández-Castellano et al. (2017) the prepartum infusion of 5-HTP did not influence postpartum concentrations of free fatty acids in dairy cows. Similar fat mobilization intensity may cause a similar stimulus in the liver parenchymal cells, which may explain the increased Hp concentration in the 5-HTP and control groups shown in the present study. As described by Jacobsen et al. (2004), Hp usually increases after an stress situation (i.e., infection or metabolic stress) and remains elevated for up to $2 \mathrm{wk}$. This fact could explain the decreased Hp concentrations observed in both groups on d 30 postpartum.

\section{CONCLUSIONS}

In conclusion, the infusion of 5 -HTP $(1 \mathrm{mg} / \mathrm{kg}$ of $\mathrm{BW}$ ) for at least $4 \mathrm{~d}$ prepartum induced calcium mobilization to the bloodstream independent of PTH. Based on the present findings, other pathways of metabolic adaptation as well as the $\operatorname{IgG}$ concentration during the onset of lactation are most likely not affected by the infusion of 5-HTP.

\section{ACKNOWLEDGMENTS}

This study was supported by a grant of the Swiss Federal Food Safety and Veterinary Office (FSVO). The expert performance of laboratory assays by Yolande Zbinden (Veterinary Physiology, Vetsuisse Faculty University of Bern, Switzerland), Thomas Blees (Physiology and Hygiene Unit, University of Bonn, Germany), and Christiane Urh (Physiology and Hygiene Unit, University of Bonn, Germany) is gratefully acknowledged.

\section{REFERENCES}

Agroscope. 2015. Fütterungsempfehlungen und nährwerttabellen für wiederkäuer (Grünes buch). Accessed Oct. 2015. AIfL Sciences, Posieux, Switzerland. 
Auldist, M. J., S. A. Turner, C. D. McMahon, and C. G. Prosser. 2007. Effects of melatonin on the yield and composition of milk from grazing dairy cows in New Zealand. J. Dairy Res. 74:52-57.

Block, S. S., W. R. Butler, R. A. Ehrhardt, A. W. Bell, M. E. Van Amburgh, and Y. R. Boisclair. 2001. Decreased concentration of plasma leptin in periparturient dairy cows is caused by negative energy balance. J. Endocrinol. 171:339-348.

Blumer, R. M. E., C. P. van Roomen, A. J. Meijer, J. H. P. M. HoubenWeerts, H. P. Sauerwein, and P. F. Dubbelhuis. 2008. Regulation of adiponectin secretion by insulin and amino acids in 3T3-L1 adipocytes. Metabolism 57:1655-1662.

Castro, N., M. Spengler, V. Lollivier, O. Wellnitz, H. H. D. Meyer, and R. M. Bruckmaier. 2011. Diurnal pattern of melatonin in blood and milk of dairy cows. Milchwissenschaft 66:352-353.

Drackley, J. K. 1999. ADSA Foundation Scholar Award. Biology of dairy cows during the transition period: The final frontier? J. Dairy Sci. 82:2259-2273.

Eastell, R., A. Colwell, L. Hampton, and J. Reeve. 1997. Biochemical markers of bone resorption compared with estimates of bone resorption from radiotracer kinetic studies in osteoporosis. J. Bone Miner. Res. 12:59-65.

Fleischer, P., M. Metzner, M. Beyerbach, M. Hoedemaker, and W. Klee. 2001. The relationship between milk yield and the incidence of some diseases in dairy cows. J. Dairy Sci. 84:2025-2035.

Garcia-Ispierto, I., A. Abdelfatah, and F. Lopez-Gatius. 2013. Melatonin treatment at dry-off improves reproductive performance postpartum in high-producing dairy cows under heat stress conditions. Reprod. Domest. Anim. 48:577-583.

Gross, J., H. A. van Dorland, R. M. Bruckmaier, and F. J. Schwarz. 2011. Performance and metabolic profile of dairy cows during a lactational and deliberately induced negative energy balance with subsequent realimentation. J. Dairy Sci. 94:1820-1830.

Halloran, B. P., and H. F. DeLuca. 1980. Skeletal changes during pregnancy and lactation: The role of vitamin D. Endocrinology 107:1923-1929.

Hernandez, L. L., K. A. Gregerson, and N. D. Horseman. 2012. Mammary gland serotonin regulates parathyroid hormone-related protein and other bone-related signals. Am. J. Physiol. Endocrinol. Metab. 302:E1009-E1015.

Hernández-Castellano, L. E., S. R. Weaver, L. L. Hernandez, and R. M. Bruckmaier. 2017. Increased serum serotonin improves parturient calcium homeostasis in dairy cows. J. Dairy Sci. 100:1580-1587.

Hiss, S., C. Weinkauf, S. Hachenberg, and H. Sauerwein. 2009. Relationship between metabolic status and the milk concentrations of haptoglobin and lactoferrin in dairy cows during early lactation. J. Dairy Sci. 92:4439-4443.

Huzzey, J. M., D. V. Nydam, R. J. Grant, and T. R. Overton. 2011 Associations of prepartum plasma cortisol, haptoglobin, fecal cortisol metabolites, and nonesterified fatty acids with postpartum health status in Holstein dairy cows. J. Dairy Sci. 94:5878-5889.

Iken, K., S. Chheng, A. Fargin, A. C. Goulet, and E. Kouassi. 1995. Serotonin upregulates mitogen-stimulated B lymphocyte proliferation through 5-HT1A receptors. Cell. Immunol. 163:1-9.

Jacobsen, S., P. H. Andersen, T. Toelboell, and P. M. H. Heegaard. 2004. Dose dependency and individual variability of the lipopolysaccharide-induced bovine acute phase protein response. J. Dairy Sci. 87:3330-3339.

Katoh, N. 2002. Relevance of apolipoproteins in the development of fatty liver and fatty liver-related peripartum diseases in dairy cows. J. Vet. Med. Sci. 64:293-307.

Kessel, S., M. Stroehl, H. H. Meyer, S. Hiss, H. Sauerwein, F. J. Schwarz, and R. M. Bruckmaier. 2008. Individual variability in physiological adaptation to metabolic stress during early lactation in dairy cows kept under equal conditions. J. Anim. Sci. 86:29032912.

Kesser, J., M. Hill, J. F. Heinz, C. Koch, J. Rehage, J. SteinhoffWagner, H. M. Hammon, B. Mielenz, H. Sauerwein, and H. Sadri 2015. The rapid increase of circulating adiponectin in neonatal calves depends on colostrum intake. J. Dairy Sci. 98:7044-7051.

Lacasse, P., C. M. Vinet, and D. Petitclerc. 2014. Effect of prepartum photoperiod and melatonin feeding on milk production and prolactin concentration in dairy heifers and cows. J. Dairy Sci 97:3589-3598.

Laporta, J., K. P. Keil, C. M. Vezina, and L. L. Hernandez. 2014a. Peripheral serotonin regulates maternal calcium trafficking in mammary epithelial cells during lactation in mice. PLoS One 9:e110190.

Laporta, J., K. P. Keil, S. R. Weaver, C. M. Cronick, A. P. Prichard, T. D. Crenshaw, G. W. Heyne, C. M. Vezina, R. J. Lipinski, and L. L. Hernandez. 2014b. Serotonin regulates calcium homeostasis in lactation by epigenetic activation of hedgehog signaling. Mol Endocrinol. 28:1866-1874

Laporta, J., S. A. Moore, S. R. Weaver, C. M. Cronick, M. Olsen, A. P. Prichard, B. P. Schnell, T. D. Crenshaw, F. Penagaricano, R. M. Bruckmaier, and L. L. Hernandez. 2015. Increasing serotonin concentrations alter calcium and energy metabolism in dairy cows. J. Endocrinol. 226:43-55.

Lauder, J. M. 2004. A role for serotonin in the mammary gland. Dev. Cell 6:165.

Lehmann, M., S. K. Wall, O. Wellnitz, and R. M. Bruckmaier. 2015. Changes in milk L-lactate, lactate dehydrogenase, serum albumin, and IgG during milk ejection and their association with somatic cell count. J. Dairy Res. 82:129-134.

Lucy, M. C. 2004. Mechanisms linking the somatotropic axis with insulin: Lessons from the postpartum dairy cow. Proc. N.Z. Soc. Anim. Prod. 64:19-23.

Marshall, A. M., L. L. Hernandez, and N. D. Horseman. 2014. Serotonin and serotonin transport in the regulation of lactation. J Mammary Gland Biol. Neoplasia 19:139-146.

Matsuda, M., T. Imaoka, A. J. Vomachka, G. A. Gudelsky, Z. Hou, M. Mistry, J. P. Bailey, K. M. Nieport, D. J. Walther, M. Bader, and N. D. Horseman. 2004. Serotonin regulates mammary gland development via an autocrine-paracrine loop. Dev. Cell 6:193-203.

Mossner, R., and K. P. Lesch. 1998. Role of serotonin in the immune system and in neuroimmune interactions. Brain Behav. Immun. 12:249-271.

Peuhkuri, K., N. Sihvola, and R. Korpela. 2012. Dietary factors and fluctuating levels of melatonin. Food Nutr. Res. 56. https://doi org/10.3402/fnr.v56i0.17252.

Rahman, M. K., T. Nagatsu, T. Sakurai, S. Hori, M. Abe, and M. Matsuda. 1982. Effect of pyridoxal phosphate deficiency on aromatic L-amino acid decarboxylase activity with L-DOPA and L-5-hydroxytryptophan as substrates in rats. Jpn. J. Pharmacol. $32: 803-811$.

Romero Barco, C. M., S. Manrique Arija, and M. Rodriguez Perez. 2012. Biochemical markers in osteoporosis: Usefulness in clinical practice. Reumatol. Clin. 8:149-152.

Sadri, H., M. Mielenz, I. Morel, R. M. Bruckmaier, and H. A. van Dorland. 2011. Plasma leptin and mRNA expression of lipogenesis and lipolysis-related factors in bovine adipose tissue around parturition. J. Anim. Physiol. Anim. Nutr. (Berl.) 95:790-797.

Saremi, B., A. Al-Dawood, S. Winand, U. Muller, J. Pappritz, D. von Soosten, J. Rehage, S. Danicke, S. Haeussler, M. Mielenz, and H. Sauerwein. 2012. Bovine haptoglobin as an adipokine: Serum concentrations and tissue expression in dairy cows receiving a conjugated linoleic acids supplement throughout lactation. Vet. Immunol. Immunopathol. 146:201-211.

Sauerwein, H., U. Heintges, A. Hennies, T. Selhorst, and A. Daxenberger. 2004. Growth hormone induced alterations of leptin serum concentrations in dairy cows as measured by a novel enzyme immunoassay. Livest. Prod. Sci. 87:189-195.

Singh, S. P., S. Haeussler, J. J. Gross, F. J. Schwarz, R. M. Bruckmaier, and H. Sauerwein. 2014. Short communication: Circulating and milk adiponectin change differently during energy deficiency at different stages of lactation in dairy cows. J. Dairy Sci. 97:1535-1542.

Skinner, J. G. 2001. International standardization of acute phase proteins. Vet. Clin. Pathol. 30:2-7.

Sugimoto, Y., I. Kimura, J. Yamada, Y. Watanabe, N. Takeuchi, and K. Horisaka. 1990. Effects of serotonin on blood glucose and insulin levels of glucose- and streptozotocin-treated mice. Jpn. J. Pharmacol. 54:93-96. 
Urena, P., A. Ferreira, V. T. Kung, C. Morieux, P. Simon, K. S. Ang, J. C. Souberbielle, G. V. Segre, T. B. Drueke, and M. C. Devernejoul. 1995. Serum pyridinoline as a specific marker of collagen breakdown and bone metabolism in hemodialysis-patients. J. Bone Miner. Res. 10:932-939.

Van Knegsel, A. T., H. M. Hammon, U. Bernabucci, G. Bertoni, R. M. Bruckmaier, R. M. Goselink, J. J. Gross, B. Kuhla, C. C. Metges, and H. K. Parmentier. 2014. Metabolic adaptation during early lactation: Key to cow health, longevity and a sustainable dairy production chain. CAB Rev. 9:15.

Vernon, R. G., R. G. Denis, A. Sorensen, and G. Williams. 2002 Leptin and the adaptations of lactation in rodents and ruminants. Horm. Metab. Res. 34:678-685.

Vicari, T., J. J. van den Borne, W. J. Gerrits, Y. Zbinden, and J. W. Blum. 2008. Postprandial blood hormone and metabolite concentrations influenced by feeding frequency and feeding level in veal calves. Domest. Anim. Endocrinol. 34:74-88.

Watanabe, H., D. Akasaka, H. Ogasawara, K. Sato, M. Miyake, K. Saito, Y. Takahashi, T. Kanaya, I. Takakura, T. Hondo, G. Z. Chao, M. T. Rose, S. Ohwada, K. Watanabe, T. Yamaguchi, and H. Aso. 2010. Peripheral serotonin enhances lipid metabolism by accelerating bile acid turnover. Endocrinology 151:4776-4786.

Watanabe, H., R. Saito, T. Nakano, H. Takahashi, Y. Takahashi, K. Sumiyoshi, K. Sato, X. Chen, N. Okada, S. Iwasaki, D. W. Har- janti, N. Sekiguchi, H. Sano, H. Kitazawa, M. T. Rose, S. Ohwada, K. Watanabe, and H. Aso. 2014. Effect of peripheral 5-HT on glucose and lipid metabolism in wether sheep. PLoS One 9:e88058.

Weaver, S. R., A. P. Prichard, E. L. Endres, S. A. Newhouse, T. L. Peters, P. M. Crump, M. S. Akins, T. D. Crenshaw, R. M. Bruckmaier, and L. L. Hernandez. 2016. Elevation of circulating serotonin improves calcium dynamics in the peripartum dairy cow. J. Endocrinol. 230:105-123.

Weber, C., C. Hametner, A. Tuchscherer, B. Losand, E. Kanitz, W. Otten, H. Sauerwein, R. M. Bruckmaier, F. Becker, W. Kanitz, and H. M. Hammon. 2013. Hepatic gene expression involved in glucose and lipid metabolism in transition cows: Effects of fat mobilization during early lactation in relation to milk performance and metabolic changes. J. Dairy Sci. 96:5670-5681.

Weber, C., C. T. Schaff, U. Kautzsch, S. Borner, S. Erdmann, S. Gors, M. Rontgen, H. Sauerwein, R. M. Bruckmaier, C. C. Metges, B. Kuhla, and H. M. Hammon. 2016. Insulin-dependent glucose metabolism in dairy cows with variable fat mobilization around calving. J. Dairy Sci. 99:6665-6679.

Wysolmerski, J. J. 2010. Interactions between breast, bone, and brain regulate mineral and skeletal metabolism during lactation. Ann. N. Y. Acad. Sci. 1192:161-169. 